\title{
PEMBELAJARAN BAHASA PADA ANAK USIA DINI MELALUI CERITA BERGAMBAR
}

\author{
Much Deiniatur \\ Dosen Institut Agama Islam Negeri Metro \\ Jl. Ki Hajar Dewantara 15A Iring Mulyo Kota Metro \\ deiniatur@gmail.com
}

\begin{abstract}
Language Skill consists of four components of speaking, writing, listening and reading. The most important thing for children is speaking, because it provides enormous benefits, one of which so that children can interact with peers and others around them and add new knowledge. Storytelling is a popular communication medium for children, training their ability to focus attention for some time on certain objects. Children are able to express themselves through a process that makes them happy and fosters a sense of satisfaction that makes them more confident. Tale or story telling is something human, that is, fairy tale or story using eye, hearing, motion, and touching heart. The benefits of storytelling activities are: 1.) Storytelling can develop children's imagination, 2.) Increasing experience, 3.) Train concentration power, 4.) Increasing the vocabulary, 5.) Creating a familiar atmosphere, 6.) comprehending, 7.) Developing social feelings, 8.) Developing children's emotions, 9.) Practicing listening, 10.) Knowing positive and negative values. 11.) Adding knowledge
\end{abstract}

Keywords: language, early childhood, story, picture

\begin{abstract}
Abstrak
Kemampuan berbahasa terdiri dari empat komponen yaitu berbicara, menulis, mendengar dan membaca. Hal yang paling penting bagi anak adalah berbicara, karena memberikan manfaat yang sangat besar, salah satunya supaya anak-anak dapat berinteraksi dengan teman sebayanya dan orang lain disekitarnya serta dapat menambah pengetahuan baru. Bercerita merupakan media komunikasi yang digemari anak-anak, melatih kemampuan mereka dalam memusatkan perhatian untuk beberapa waktu terhadap objek tertentu. Anak - anak mampu berekspresi melalui proses yang membuat mereka senang dan menumbuhkan rasa puas sehingga membuat mereka lebih percaya diri. Dongeng atau bercerita itu sesuatu yang manusiawi, artinya, dongeng atau cerita menggunakan mata, pendengaran, gerak, dan hatinya juga ikut merasakan. Adapun manfaat dari kegiatan mendongeng adalah: 1.) Mendongeng dapat mengembangkan imajinasi anak, 2.) Menambah pengalaman, 3.) Melatih daya konsentrasi, 4.) Menambah perbendaharaan kata, 5.) Menciptakan suasana yang akrab, 6.) Melatih daya tangkap, 7.) Mengembangkan perasaan sosial., 8.) Mengembangkan emosi anak, 9.) Berlatih mendengarkan, 10.) Mengenal nilai-nilai positif dan negative. 11.) Menambah pengetahuan
\end{abstract}

Kata Kunci: bahasa, anak usia dini, cerita, bergambar 


\section{Pendahuluan}

Bahasa merupakan kemampuan untuk berkomunikasi dengan orang lain. Hal ini mencakup semua cara untuk berkomunikasi seperti mengungkapkan pikiran dan perasaan melalui lambang atau simbol dengan menggunakan lisan, tulisan, isyarat, bilangan, lukisan, dan mimik muka.

Untuk dapat berkomunikasi secara efektif dengan orang lain, manusia dituntut untuk mempunyai kemampuan berbahasa. Bahasa merupakan faktor penting yang membedakan manusia dengan hewan.

Dengan bahasa, manusia dapat mengenal dan memahami dirinya, sesama, dan lingkungan hidupnya. Manusia dapat mengutarakan ide-ide, gagasan pemikiran, hal-hal yang disukai dan tidak di sukai melalui bahasa yang dimilikinya. Manusia dapat berkomunikasi dengan sesamanya walaupun masing-masing berasal dari latar belakang budaya berbeda.

Dengan bahasa manusia dapat mentransformasikan ide-ide atau hasil pemikiran dari sebuah ilmu pengetahuan. Hasil pemikiran harus disampaikan kepada masyarakat luas melalui bahasa. Oleh karena itu, perkembangan bahasa harus dirangsang sejak dini.

Kemampuan berbahasa anak merupakan hal yang penting karena dengan bahasa anak dapat berkomunikasi dengan temantemannya. Bahasa merupakan instrumen utama dalam mengekspresikan pikiran dan pengetahuan bila anak mengadakan hubungan dengan orang lain. Anak-anak yang sedang berkembang mengkomunikasikan kebutuhan, pikiran dan perasaannya melalui bahasa dengan kata-kata yang mempuyai makna.

Bahasa bagi anak-anak merupakan hal yang sangat penting, karena dengan bahasa anak-anak mampu mengungkapkan segala apa yang ia rasakan kepada orang lain. Selain itu, anak juga dapat berkomunikasi dengan lingkungan sekitar, dan sebagai sarana untuk menyalurkan ekspresi anak. Begitu pentingnya bahasa bagi manusia, maka dalam kegiatannya manusia selalu menggunakan bahasa sebagai alat atau sarana untuk berkomunikasi antar sesamanya, karena bahasa adalah alat yang digunakan untuk membentuk pikiran.

Berbahasa terdiri dari empat komponen yaitu berbicara, menulis, mendengar dan membaca. Hal yang paling penting bagi anak adalah berbicara, karena memberikan manfaat yang sangat besar, salah satunya supaya anak-anak dapat berinteraksi dengan teman sebayanya dan orang lain disekitarnya serta dapat menambah pengetahuan baru.

Kemampuan berbahasa yang paling efektif dilakukan adalah kemampuan berbicara. Salah satu cara untuk mengembangkan kemampuan berbahasa adalah melalui cerita bergambar karena dengan media ini anak-anak akan merasa senang untuk mendengarkan cerita-cerita yang dapat meningkatkan kosa-kata bagi anak-anak. 


\section{Pembahasan}

\section{Konsep dasar Pendidikan Anak \\ Usia Dini}

Pendidikan Anak Usia Dini mempunyai peran yang sangan strategis dalam menentukan sejarah perkembangan anak karena merupakan pondasi bagi kepribiadian anak. Anak yang mendapatkan pembinaan yang tepat dan efektif sejak usia dini akan dapat meningkatkan kesehatan fisik dan mental yang berdampak pada peningkatan prestasi belajar anak, etos kerja anak, dan produktifitas sehingga mampu mandiri dan mengoptimalkan potensi dirinya.

Suyadi dan Maulidia Ulfah menyatakan bahwa Pendidikan Anak Usia Dini dapat diartikan sebagai salah satu bentuk penyelenggaraan pendidikan yang menitikberatkan pada peletakan dasar ke arah pertumbuhan dan perkembangan, baik koordinasi motorik (halus dan kasar), kecerdasan emosi, kecerdasan jamak (multiple intelligence) maupun kecerdasan spiritual. ${ }^{1}$

Adapun tujuan Pendidikan Anak Usia Dini adalah sebagai berikut ini:

a. Anak mampu melakukan ibadah.

b. Anak mampu mengelola keterampilan tubuh.

c. Anak mampu menggunakan bahasa.

d. Anak mampu berpikir secara kritis dan logis.

e. Anak mampu mengenal lingkungan alam

${ }^{1}$ Suyadi dan Maulidiya Ulfah, Konsep Dasar PAUD, (Bandung: PT Rosdakarya, 2012), h.17 f. Anak memiliki kepekaan terhadap irama dan nada2

Sedangakan dalam UU No.20 tahun 2003 tentang Sistem Pendidikan Nasional menyatakan bahwa PAUD adalah suatu upaya pembinaan yang ditujukan kepada anak sejak lahir sampai dengan usia 6 tahun yang dilakukan melalui pemberian rangsangan pendidikan untuk membantu pertumbuhan dan perkembangan jasmani dan rohani agar anak memiliki kesiapan dalam memasuki pendidikan yang lebih lanjut. ${ }^{3}$

Pendidikan anak usia dini pada dasarnya harus meliputi aspek kelimuan yang menunjang kehidupan anak dan terkait dengan perkembangan anak. Konsep kelimuan PAUD bersifat Isomorfis artinya kerangka kelimuan PAUD dibangun dari interdisiplin ilmu yang merupakan gabungan dari beberapa disiplin ilmu diantaranya psikologi, fisiologi, sosiologi, ilmu pendidikan anak, antropologi, humaniora, kesehatan, gizi, dan neurosains. ${ }^{4}$

Dalam UU RI Nomor 20 tahun 2003 tentang Sistem Pendidikan Nasioanal pada Bab VI Pasal 28 menyatakan bahwa:

a. Pendidikan Anak Usia Dini diselenggarakan sebelum jenjang pendidikan dasar.

b. Pendidikan Anak Usia Dini dapat diselenggarakan melalui jalur pendidikan formal, non formal, dan/atau informal.

c. PAUD pada jalur pendidikan formal berbentuk TK, RA, atau bentuk lain yang sederajat.

\footnotetext{
${ }^{2}$ Mursyid, Belajar dan Pembelajaran PAUD, (Bandung:PT Rosdakarya), h.17

${ }^{3}$ UU No.20 tahun 2003 tentang Sistem Pendidikan Nasional

4 Yuliani Nuraini Sujono, Konsep Dasar Pendidikan Anak

Usia Dini, (Jakarta: PT Indeks, 2009), h.10
} 
d. PAUD pada jalur pendidikan nonformal berbentuk KB, TPA, atau bentuk lain yang sederajat.

e. PAUD pada jalur pendidikan informal berbentuk pendidikan keluarga atau pendidikan yang diselenggarakan oleh pendidikan.

\section{PAUD mengembangkan}

potensi anak secara komprehensif, artinya bahwa pemberian rangsangan melalui pendidikan untuk anak usia dini perlu diberikan secara komprehensif, dalam arti anak tidak hanya dicerdaskan otaknya saja, tetapi juga harus dicerdaskan pada aspekaspek lain dalam kehidupannya seperti budi pekerti, panca indera, aspek sosial dan juga dalam berbahasa.

Penyelenggara PAUD harus mempunyai akuntabilitas yang tinggi sehingga tujuan PAUD dapat tercapai. Untuk itu diperlukan adanya pihak yang terus mengkaji dan membantu penyelenggaraan program untuk terus mencari model yang tepat untuk kemajuan PAUD.

\section{Karakteristik Anak Usia Dini}

Menurut Harlock dalam Suyadi dan Maulidya Ulfah ada beberapa faktor yang mempengaruhi tumbuh kembang anak, yaitu:

a. Faktor lingkungan sosial yang menyenangkan anak

Hubungan anak dengan masyarakat yang menyenangkan dengan anggota keluarga dapat mendorong anak mengembangkan kecenderungan menjadi terbuka. b. Faktor emosi

Perpisahan dengan orang tua dapat menimbulkan gangguan kepribadian pada anak. Sebaliknya pemuasan emosional mendorong perkembangan kepribadian anak semakin stabil.

c. Metode mendidik anak

Anak-anak yang dibesarkan dalam keluarga permisif, diprediksi akan cenderung kehilangan rasa tanggung jawab, mempunyai kendali emosi yang rendah, dan berprestasi rendah. Sedangkan mereka yang dibesarkan oleh orang tua secara demokratis, penyesuaian pribadinya dan sosialnya lebih baik.

d. Beban tanggung jawab berlebihan

Anak pertama sering diharapkan untuk lebih bertanggungjawab, terutama kepada adik-adiknya. Hal ini akan berpotensi untuk mengembangkan kebiasaan memerintah.

e. Faktor keluarga di masa anak-anak

Anak yang tumbuh di keluarga besar akan bersikap otoriter. Sedangkan anak yang tumbuh ditengah keluarga cerai kemungkinan besar akan menjadi anak yang cemas, tidak mudah percaya, dan sedikit kaku.

f. Faktor rangsangan lingkungan

Lingkungan yang merangsang dapat mendorong perkembangan fisik dan mental anak secara baik, sedangkan lingkungan yang tidak merangsang dapat menimbulkan perkembangan anak dibawah kemampuannya. ${ }^{5}$

\footnotetext{
5 Suyadi dan Maulidya Ulfah, Konsep Dasar PAUD,(Bandung: Rosdakarya, 2015), h.56-57
} 


\section{Perkembangan Bahasa Pada Anak}

\section{Usia Dini}

\section{a. Teori Perkembangan Bahasa} Anak

Menurut Abdul Chaer, bahwa terdapat tiga pandangan mengenai teori perkembangan bahasa anak yaitu Nativisme yang wakili oleh Noam Chomsky, Behaviorisme yang diwakili oleh B.F Skiner, dan Kognitivisme yang diwakili oleh Jean Piaget. ${ }^{6}$

1) Teori nativisme

Nativisme berpandapat bahwa dalam Proses pemerolehan bahasa pertama, anak-anak sedikit demi sedikit membuka kemampuan bahasanya secara genetic. Dalam teori ini anak dilahirkan dibekali dengan alat pemerolehan bahasa (Language Acquisition Device/LAD) yaitu alat yang sudah diprogramkan secara biologis.

Para ahli nativis berpendapat

bahwa kemampuan berbahasa adalah sifatnya sangat natural (bawaan) sebagimana halnya kemampuan berjalan, hal itu merupakan bagian dari perkembangan manusia yang dipengaruhi oleh kematangan otak. Mereka juga meyakini bahwa anakanak menginternalisasikan aturan tata bahsa sehingga mereka mampu untuk menyusun berbagai macam kalimat tanpa latihan, penguatan, dan meniru bahasa orang dewasa. ${ }^{7}$

6 Abdul Chaer, Psikolinguistik: Kajian teoritik,(Jakarta: PT Rineka Cipta,2002), h 221

7 Ahmad Susanto, Pendidikan Anak Usia Dini (Konsep dan Teori), (Jakarta: PT. Bumi Aksara,2017), h.165
2) Teori behavioristik

Kaum Behavioris menyatakan bahwa proses pemerolehan bahasa pertama dikendalikan oleh dari Luar anak atau rangsangan yang diberikan oleh lingkungan. Pandangan teori ini beranggapan bahwa bahasa merupakan masalah respond dan sebuah imitasi. Para tokoh behavioris berpendapat bahwa keterampilan dasar bahasa anak dipelajari melalui pembiasaan dari lingkungan dan męrupakan hasil imitasi terhadap orang dewasa. ${ }^{8}$

3) Teori kognitivisme

Menurut pandangan

Kognitivisme, bahasa itu bukanlah suatu cirri alamiah yang terpisah, melainkan salah satu diantara beberapa kemampuan yang berasal dari kematangan kognitif atau dengan kata lain Bahasa berasal dari nalar.

Semua Bahasa yang dimiliki manusia pasti terdapat aturan ketatabahasaan seperti Fonologi, morfologi, sintaksis, semantic, dan pragmatis. $^{9}$

Fonologi merupakan Sistem Bunyi atau suara dalam bahasa. Dalam mempelajari fonologi bahasa, anak harus mempelajari kandungan suaranya dan urutan suara yang diperbolehkan dan sangat penting untuk latihan membaca kelak. Seperti bunyi "a", "b", dan "c".

Morfologi adalah aturan untuk mengombinasikan morfem, yaitu rangkian suara yang membentuk kesatuan bahasa terkecil. Contohnya ba-

\footnotetext{
${ }^{8} \mathrm{Ibid}$

9 Zusy Aryanti, Psikologi Perkembangan. (STAIN JuraiSiwo Metro), 2015. h. 85
} 
ju, terdiri dua morfem.

Siktaksis

adalah

peengkombinasian kata untuk membentuk frasa dan kalimat yang bisa diterima.contohnya jika seorang berkata "Bob dipukul oleh Tom" maka kita tahu siapa yang memukul dan siapa yang dipukul.

Semantik adalah makna dari kata atau kalimat. Misalnya gadis dan wanita mempunyai makna semantic yang sama yaitu manusia berjenis kelamin perempuan, tetapi berbeda dalam umurnya.

Pragmatis adalah penggunaan percakapan yang tepat, melibatkan pengetahuan tentang pengetahuan mengenai konteks apa yang dikatakan dan kepada siapa dikatakan. Misalnya anak-anak yang belajar membedakan bahasa sopan dan kasar. Tahap Perkembangan Bahasa pada Anak-anak

Menurut Guntur dalam Susanto, tahapan perkembangan bahasa anak usia dini adalah sebagai berikut ini:

1) Tahap I (pralinguistik) yaitu antara 0-1 tahun. Tahap ini terdiri dari:

a) Tahap meraban-1

(Pralinguistik pertama).

Tahap ini dimulai dari bulan pertama hingga bulan keenam dimana anak akan mulai menagis dan menjerit.

b) Tahap meraban-2 (Pralinguistik kedua). Tahap ini pada dasarnya merupakan tahap kata tanpa makna mulai dari bulan ke 6 hingga 1 tahun.

2) Tahap II (linguistic). Tahap ini terdiri dari tahap I dan II, yaitu:

a) Tahap-1: holafrastik (1tahun), ketika anak-anak mulai menyatakan makna dalam keseluruhan frasa atau kalimat dalam satu kata. Tahap ini juga ditandai dengan perbendaharaan kata anak hingga kurang lebih 50 kosa kata.

b) Tahap-2: Frasa (1-2), pada tahap ini anak sudah mampu mengucapkan dua kata (ucapan dua kata). Tahap ini juga ditandai dengan perbendaharaan kata anak sampai dengan rentang 50-100 kata.

3) Tahap III (pengembangan tata bahasa, yaitu prasekolah 3,4,5 tahun). Pada tahap ini anak sudah dapat membuat kalimat, seperti telegram. Dilihat dari aspek perkembangan tata bahasa sperti: S-P-O, anak dapat memperpanjang kata menjadi satu kalimat.

4) Tahap IV (tata bahasa menjelang dewasa, yaitu 6-8 tahun). Tahap ini ditandai dengan kemampuan yang mampu menggabungkan kalimat sederhana dan kalimat kompleks. ${ }^{10}$

$\begin{array}{lrr}\text { Sementara menurut } & \begin{array}{r}\text { Mursyid, } \\ \text { dalam }\end{array} \\ \text { tahapan-tahapan } & \text { umum } & \text { berbahasa } \\ \text { perkembangan kemampuan } & \text { bemal berikut ini: }\end{array}$

10 Ahmad Susanto, Perkembangan Anak Usia Dini; Pengantar dalam Berbagai Aspeknya. (Jakarta: Kencana, 2014), h.75-76. 
1) Reflexive vocalization

Pada usia 0-3 minggu bayi akan mengeluarkan tangisan yang masih berupa refleks. Jadi bayi menangis bukan karena ia memang ingin menangis, tetapi hal tersebut dilakukan tanpa ia sadari.

\section{2) Babling}

Pada usia lebih dari seminggu, ketika bayi merasa lapar atau tidak nyaman, ia akan mengeluarkan suara tangisan. Berbeda dengan sebelumnya, tangisan yang dikeluarkan telah dapat dibedakan sesuai dengan keinginan atau perasaan si bayi.

\section{3) Lalling}

Dalam usia 3 minggu sampai 2 bulan mulai terdengar suarasuara tetapi belum jelas.

\section{4) Echolia}

Di tahap ini, saat bayi menginjak usia 10 bulan mulai bisa menirukan suara-suara yang didengar lingkungannya, serta juga akan menggunakan ekspresi wajah atau isyarat tangan ketika ingin meminta sesuatu.

5) True speech

$$
\text { Bayi dapat mulai dapat }
$$

berbicara dengan benar, pada saat usianya meginjak 18 bulan atau bisa disebut balita. Namun, pengucapannya belum sempurna seperti orang dewasa. ${ }^{11}$

11 Mursyid, Belajar dan Pembelajaran PAUD, (Bandung:PT Rosdakarya,2015), h.9
Selanjutnya,

helmawati menjelaskan program pembelajaran bahasa pada PAUD sebagai berikut ini ${ }^{12}$ :

1) Anak Usia Dini 0-3 Bulan

Anak usia ini baru dapat mengeluarkan suara untuk menyatakan keinginan atau sebagai reaksi atas rangsangan seperti menangis, berteriak, dan bergumam

2) Anak Usia Dini 3-6 bulan

Mengeluarkan suara untuk menyataka keinginan atau sebagai reaksi atas rangsangan yaitu memperhatikan atau mendengarkan ucapan orang, mengoceh, dan tertawa kepada orang yang mengajak komunikasi.

\section{3) Anak Usia Dini 6-9 bulan}

Mengeluarkan suara untuk menyatakan keinginan atau sebagai reaksi atas rangsangan yaitu mulai meniru ucapan, merespon permainan cilukba, dan menunjuk benda dengan mengucapkan satu kata.

4) Anak Usia Dini 9-12 bulan

Mengucapkan dua kata untuk menyatakan keinginan, menyatakan penolakan, dan menyebutkan nama benda atau binatang (pus untuk ayam atau kut-kut-kut untuk ayam.

5) Anak Usia Dini 1-1,5 tahun

a) Menerima bahasa: menunjuk bagian tubuh yang ditanyakan dan memahami tema cerita pendek.

\footnotetext{
12 Helmawati,Mengenal dan memahami PAUD, (Bandung:PT Rosdakarya, 2015), h. 85
} 
b) Mengungkapkan bahasa: merespon pertanyaan dengan jawaban "ya atau tidak" dan mengucapkan kalimat yang terdiri atas dua kata.

6) Anak Usia Dini 1,5-2 tahun

a) Menerima bahasa: menaruh perhatian pada gambargambar dalam buku dan menggunakan kata-kata sederhana untuk menyatakan keingintahuan.

b) Mengungkapkan bahasa: menjawab pertanyaan dengan kalimat pendek dan menyanyikan lagu sederhana.

7) Anak Usia Dini 2-3 tahun

a) Menerima bahasa: hafal beberapa lagu anak yang sederhana, memahami cerita atau dongeng sederhana, dan mampu memahami perintah sederhana seperti: letakkan mainan diatas meja atau ambil mainan dari dalam kotak.

b) Mengungkapkan bahasa: menggunakan kata tanya dengan tepat (apa, siapa, bagaimana, mengapa, dimana).

8) Anak Usia Dini 3-4 tahun

a) Menerima bahasa:

- Pura-pura membaca cerita bergambar dalam buku dengan kata-kata sendiri.

- Mulai memahami dua perintah yang diberikan bersamaan, contoh: ambil mainan diatas meja dan berikan kepada ibu.

b) Mengungkapkan bahasa:

- Mulai menyatakan keinginan dengan mengucapkan kalimat sederhana (contoh: saya ingin main bola).

- Mulai menceritakan pengalaman yang dialami dengan cerita sederhana.

9) Anak Usia Dini 4-5 tahun

a) Menérima bahasa:

Menyimak perkataan orang lain (bahasa ibu atau bahasa lainnya)

- Mengerti dua perintah yang diberikan bersamaan

- Memahami cerita yang dibacakan.

- Mengenal perbendaharaan kata mengenai kata sifat (nakal, pelit, baik hati, berani, baik, jelek, dan sebagainya.)

b) Mengungkapkan bahasa:

- Mengulang kalimat sederhana.

- Menjawab pertanyaan sederhana.

- Mengungkapkan perasaan dengan kata sifat (baik, senang, nakal, pelit, baik hati, berani, baik, jelek, dan sebagainya).

- Menyebutkan kata-kata yang dikenal.

- Mengutarakan pendapat kepada orang lain. 
- Menyatakan alasan terhadap sesuatu yang diinginkan atau ketidaksetujuan.

- Menceritakan kembali cerita atau dongeng yang pernah didengar.

10) Anak Usia Dini 5-6 tahun

a) Menerima bahasa:

- Mengerti beberapa perintah secara bersamaan.

- Mengulang kalimat yang lebih kompleks.

- Memahami aturan dalam suatu permainan.

b) Mengungkapkan bahasa:

- Menjawab pertanyaan yang lebih kompleks.

- Menyebutkan kelompok gambar yang memiliki bunyi yang sama.

- Berkomunikasi secara lisan, memiliki perbendaharaan kata, serta mengenal simbolsimbol untuk persiapan membaca, menulis, dan berhitung.

Menyusun kalimat sederhana dalam struktur lengkap (pokok kalimatpredikat-keterangan).

- Memiliki lebih banyak kata-kata untuk mengekspresikan ide pada orang lain.

- Melanjutkan sebagian cerita atau dongeng yang telah diperdengarkan.

\section{b. Faktor-faktor yang mempengaruhi perkembangan bahasa anak}

Ada beberapa faktor yang mempengaruhi perkembangan bahasa anak, yaitu:

1) Lingkungan yang positif dan bebas tekanan.

Sebagaimana disebutkan di atas, bahwa lingkungan yang kaya bahasa akan menstimulasi perkembangan bahasa anak. Stimulasi tersebut akan optimal jika anak tidak merasa tertekan. Anak yang tertekan dapat menghambat kemampuan bicaranya. Dapat ditemukan anak gagap yang disebabkan karena tekanan dari lingkungannya

2) Tunjukkan sikap dan minat yang tulus.

Anak usia dini emosinya masih kuat. Karena itu orang tua dan guru harus menunjukkan minat dan perhatian tinggi kepada anak. Orang dewasa perlu merespon anak dengan tulus.

3) Sampaikan pesan secara verbal diikuti nonverbal (gerakan tubuh atau mimik muka) secara konsisten.

Dalam bercakap-cakap dengan anak, orang dewasa perlu menunjukkan ekspresi yang sesuai dengan ucapannya. Perlu diikuti gerakan, mimik muka, dan intonasi yang sesuai. Misalnya: orang dewasa berkata,"saya sayang" maka perlu dikatakan dengan ekspresi muka senang dan menunjukkan rasa sayangnya, sehingga anak mengetahui seperti apa kata sayang itu sesungguhnya. 
4) Sertai bahasa verbal dengan intonasi yang sesuai.

Intonasi merupakan menggunakan nada ketika berbicara. Dengan menggunakan intonasi yang tepat, anak-anak akan terangsang untuk mendengarkan orang yang berbicara. Karakter anak-anak yang suka meniru akan menirukan orang dewasa yang berbicara.

5) Terapkan bukan hanya komunikasi satu arah, tetapi juba bangun komunikasi dua arah dengan anak sejak usia dini.

Orang dewasa perlu melibatkan anak untuk ikut membangun komunikasi. Kita menghargai ide-idenya dan memberikan respon yang baik terhadap bahasa anak. ${ }^{13}$

Sedangkan menurut Syamsu Yusuf dalam bukunya yang berjudul Psikolog Perkembangan Anak dan Remaja menyatakan Perkembangan bahasa dipengaruhi oleh:

1) Faktor Kesehatan

Jika anak mengalami sakit terus-menerus pada usia dua tahun pertama, maka anak akan mengalami keterlambatan atau kesulitan dalam perkembangan bahasanya. Orang tua harus memperhatikan kesehatan dengan cara memberikan ASI, makanan yang bergizi, memelihara kebersihan tubuh, dan memeriksakan anak ke Puskesmas secara rutin.

2) Intelegensi

Anak yang mempunyai perkembangan bahasa yang cepat, biasanya tingkat intelegensinya normal atau diatas normal. Namun tidak semua anak yang mengalami keterlambatan bahasa adalah anak yang bodoh.

3) Status Sosial Keluarga

Anak yang dari keluarga miskin dapat mengalami keterlambatan dalam perkembangan bahasa dibanding keluarga yang lebih baik. Hal ini diakibatkan oleh perbedaan kesempatan belajar.

4) Jenis Kelamin

Pada usia dua tahun, anak wanita akan menunjukkan perkembangan bahasa yang lebih cepat daripada laki-laki.

5) Hubungan Keluarga.

Peran orang tua sangat penting dalam perkembangan bahasa anak karena orang tua memberikan contoh berbahasa yang baik kepada anak. Hubungan yang harmonis juga dapat membantu perkebangan bahasa pada anak dengan baik. ${ }^{14}$

14 Syamsu Yusuf, Psikologi Perkembangan Anak dan Remaja. (Bandung: Rosdakarya, 2012), h.119-120.

\footnotetext{
13 Helmawati, Pendidik sebagai Model, (Bandung:
} PT Rosdakarya, 2015), h.113 
c. Strategi Pembelajaran Bahasa pada Anak Usia Dini melalui Cerita Bergambar

Bahasa merupakan alat komunikasi antaranggota masyarakat berupa simbol bunyi yang dihasilkan oleh alat ucap manusia. Penggunaan bahasa sangat penting dalam kehidupan manusia. Hal ini dilakukan untuk menyampaikan ide, pikiran, perasaan, dan informasi kepada orang lain. Menggunakan teknik mengajar yang bervariasi bertujuan untuk membuat pembelajaran tidak jenuh dan monoton.

Strategi Pembelajaran meliputi kegiatan atau pemakaian teknik yang dilakukan oleh pengajar yang dimulai dari perencanaan, pelaksanaan pembelajaran, tahap evaluasi, dan program tindak lanjut dari pembelajaran. Strategi pembelajaran bahasa adalah tindakan pengajar dalam melaksanakan rencana mengajar bahasa seperti tujuan, bahan, metode dan alat, serta evaluasi. Program tersebut bertujuan untuk membuat situasi pembelajaran yang menuntut peserta didik untuk dapat melaksanakan aktivitas mental dan intelektual secara optimal untuk memperoleh keterampilan berbahasa yang terdiri dari unsur keterampilan menyimak, keterampilan berbicara, keterampilan membaca, dan keterampilan menulis. ${ }^{15}$

15 Iskandarwassid dan Dadang Sunendar. Strategi Pembelajaran Bahasa.( Bandung: Rosdakarya. 2013), h. 19.
Kemampuan berbahasa yang paling umum dan efektif dilakukan adalah kemampuan berbicara. Salah satu cara untuk mengembangkan kemampuan berbahasa adalah dengan melalui bercerita kepada anak-anak melalui gambar.

Teknik bercerita dengan gambar atau islustrasi dapat membantu pendidik dalam mendongeng dengan cerita yang panjang. Hal ini dilakukan agar anak-anak tetap terpikat dan berkonsentrasi mendengarkan cerita. Terlebih anak usia dini masih dalam taraf berikir konkret. Teknik ini sangat cocok untuk menarik perhatian dan konsentrasi anak pada cerita yang disampaikan oleh guru.

Menurut Suyanto dalam Susanto, melatih anak belajar bahasa dapat dilakukan melalui cara berkomunikasi dengan cara sebagai berikut:

a) Kegiatan bermain bersama, biasanya anak-anak secara otomatis berkomunikasi dengan temannya sambil bermain bersama.

b) Cerita, baik mendengar maupun menyuruh anak untuk bercerita.

c) Bermain peran, seperti memerankan penjual dan pembeli, guru dan murid, atau orang tua dan anak.

d) Bermain puppet dan boneka tangan yang dapat dimainkan dengan jari (fingerplay), anak berbicara mewakili boneka ini.

e) Belajar dan bermain dalam kelompok (cooperative play dan cooperative learning).$^{16}$

Bercerita adalah suatu metode yang digunakan untuk mengembangkan

\footnotetext{
16 Ahmad Susanto. Perkembangan Anak Usia Dini; Pengantar dalam berbagai aspeknya. (Jakarta: Kencana, 2014), h 75
} 
kemampuan berbicara yang bertujuan untuk memberikan informasi. Metode bercerita merupakan metode yang dapat digunakan dalam pembelajaran berbahasa/ berbicara karena anak akan dengan mudah mempelajari dan menyerap isi cerita. Dengan metode becerita ini guru dapat memasukan unsur-unsur edukatif guna membiasakan perilaku baik seperti tokoh cerita, memunculkan ide, berupa pertanyaan, komentar anak, sehingga dapat diketahui kecerdasan anak dalam berbicara dan berbahasa.

Bercerita merupakan media komunikasi yang digemari anak-anak, melatih kemampuan mereka dalam memusatkan perhatian untuk beberapa waktu terhadap objek tertentu. Anak anak mampu berekspresi melalui proses yang membuat mereka senang dan menumbuhkan rasa puas sehingga membuat mereka lebih percaya diri. Dongeng atau bercerita itu sesuatu yang manusiawi, artinya, dongeng atau cerita menggunakan mata, pendengaran, gerak, dan hatinya juga ikut merasakan. ${ }^{17}$

Metode bercerita adalah salah satu metode yang dapat digunakan untuk pembelajaran bagi anak dengan cara pembawaannya menarik serta mengundang perhatian anak, namun tidak lepas dari tujuan pendidikan bagi anak. Apabila isi dari cerita tersebut dekat dengan kehidupan anak, maka anak akan mudah mendengarkan dan memahami konten dalam cerita

17 Andi Asfandiyar. Cara Pintar Mendongeng. (Bandung: Dar Mizan, 2007), h.30 tersebut. ${ }^{18}$

Bercerita atau mendongeng merupakan warisan budaya yang sudah mengakar bahkan menjadi tradisi para orang tua dalam menidurkan anak. Melalui cerita orang tua atau pendidik dapat memberikan informasi yang mengandung muatan pesan moral, nilai-nilai agama, dan keteladanan.

Dalam buku Pedoman Materi TK oleh Diknas seperti yang dikutip dalam Cyrus Lalompoh dan Kartini Lalompoh mengemukakan makna prinsip bercerita bagi perkembangan anak usia dini adalah sebagai berikut:

a. Mengomunikasikan nilai-nilai budaya.

b. Mengomunikasikan nilai-nilai sosial.

c. Mengomunukasikan nilai-nilai keagamaan.

d. Menanamkan etos kerja, etos waktu, dan etos alam.

e. Membantu mengembangkan fantasi anak.

f. Mengembangkan dimensi kognitif anak.

g. Membantu mengembangkan dimensi bahasa anak. ${ }^{19}$

Adapun langkah-langkah pembelajaran bahasa dengan cerita bergambar adalah sebagai berikut:

1) Guru dapat memulai kegiatan pembelajaran dengan berdoa. Kemudian menyampaikan hari, tanggal, bulan dan tahun kepada anak. Setelah itu guru menyampaikan tema pada hari tersebut serta diikuti dengan kegiatan apersepsi yang dilakukan oleh guru kepada anak.

\footnotetext{
18 Moeslichatoen, Metode Pengajaran di Taman Kanakkanak. (Jakarta: Rineka Cipta), h. 157.

19 Cyrus Lalompoh dan kartini Lalompoh, Metode Pengembangan Moral dan Nilai-nilai Keagamaan bagi Anak Usia Dini., (Jakarta: Grasindo, 2017), h. 104-105
} 
2) Guru mulai melakukan kegiatan bercerita sesuai dengan tema disertai media gambar yang sudah disiapkan.

3) Guru memberikan pertanyaan kepada anak tentang isi cerita yang sudah disampaikan oleh guru kepada anak, guru memberikan kesempatan kepada anak untuk menjawab pertanyaan yang diajukan oleh guru serta memberi kesempatan anak untuk menceritakan kembali isi cerita yang telah disampaikan oleh guru.

4) Guru melakukan refleksi terhadap kegiatan yang sudah dilakukan selama satu hari kepada anak dengan melakukan tanya jawab, bagaimana perasaan anak hari ini? Apakah bahagia, senang, sedih dan lain sebagainya.

Adapun manfaat dari kegiatan mendongeng atau bercerita menurut Tadkirotun Musfiroh, manfaat metode bercerita adalah:

1) Membantu Pembentukan Pribadi dan Moral anak. Cerita sangat efektif untuk mempengaruhi cara berpikir dan berperilaku anak karena mereka senang mendengarkan cerita walaupun dibacakan secara berulang-ulang.

2) Menyalurkan Kebutuhan Imajinasi dan Fantasi. Pada saat menyimak cerita, imajinasi anak mulai dirangsang. Anak dapat melihat hutan, melihat sang tokoh berjalan, menemui rintangan, dan berusaha mengatasi rintangan itu.

3) Memacu Kemampuan Verbal Anak. Cerita mendorong anak belajar tata cara berdialog dan bernarasi dan terangsang untuk menirukannya. Kemampuan verbal anak lebih terstimulasi secara efektif pada saat guru melakukan semacam tes pada anak untuk menceritakan kembali isi cerita.

4) Merangsang Minat Menulis Anak. Cerita memancing rasa kebahasaan anak. Anak yang gemar mendengar dan membaca cerita akán memiliki kemampuan berbicara, menulis, dan memahami gagasan rumit secara lebih baik.

5) Merangsang Minat Baca Anak. Bercerita dengan media buku menjadi stimulasi yang efektif bagi anak Taman Kanakkanak, karena pada waktu itu minat baca pada anak mulai tumbuh.

6) Membuka Cakrawala Pengetahuan Anak. Cerita seorang guru dapat menstimulasi anak untuk belajar lebih jauh. Cerita guru yang menarik tentang ilmu pengetahuan menggerakkan anak untuk mencari tahu lebih banyak. ${ }^{20}$

Sedangkan menurut Safrudin Aziz, manfaat dari kegiatan mendongeng adalah:

1) Mendongeng dapat mengembangkan imajinasi anak.

2) Menambah pengalaman.

3) Melatih daya konsentrasi.

4) Menambah perbendaharaan kata.

5) Menciptakan suasana yang akrab.

6) Melatih daya tangkap.

7) Mengembangkan perasaan sosial.

8) Mengembangkan emosi anak.

20 Tadkiroatun Musfiro, Bercerita Untuk Anak Usia Dini. (Jakarta: Departemen Pendidikan Nasional Direktorat Jenderal Pendidikan Tinggi Direktorat Pembinaan Pendidikan Tenaga Kependidikan dan Ketenagaan Perguruan Tinggi,2005). h. 95-115. 
9) Berlatih mendengarkan

10) Mengenal nilai-nilai positif dan negative.

11) Menambah pengetahuan. ${ }^{21}$

\section{Kesimpulan}

Metode bercerita memiliki banyak manfaat bagi perkembangan berbahasa dan berbicara anak. Dengan kegiatan bercerita yang dilengkapi dengan gambar, diharapkan dapat mengembangkan kemampuan berbicara anak dengan meneruskan alur cerita dan menceritakannya kembali dengan baik.

Penggunaan buku cerita yang disertai gambar mempunyai manfaat yang sangat besar dalam proses pembelajaran. Hal ini dikarenakan gambar dapat membuat suatu objek menjadi lebih nyata, mengatasi ruang dan waktu, memperjelas objek, serta gambar dapat mudah dan murah pengadaannya. Yang paling penting bahwa gambar dapat meningkatkan minat dan motivasi belajar anak dalam berbicara untuk mengutarakan pendapat dan pemikirannya. Dalam hal ini gambar dapat memotivasi anak dalam meningkatkan kemampuan berbicara.

\section{Daftar Pustaka}

Abdul Chaer, Psikolinguistik: Kajian teoritik, (Jakarta: PT Rineka Cipta,2002)

Ahmad Susanto, Pendidikan Anak Usia Dini (Konsep dan Teori), (Jakarta:

${ }^{21}$ Safrudin Aziz, Strategi Pembelajaran Aktif Anak Usia Dini; Pandua Bagi Guru, Orang Tua, Konselor, dan Praktisi Anak Usia Dini, (Yogyakarta: Kalimedia, 2017). h. 129
PT. Bumi Aksara, 2017)

Ahmad Susanto, Perkembangan Anak Usia

Dini; Pengantar dalam Berbagai

Aspeknya. (Jakarta: Kencana, 2014)

Andi Asfandiyar. Cara Pintar Mendongeng.

(Bandung: Dar Mizan, 2007)

Cyrus Lalompoh dan kartini Lalompoh,

Metode Pengembangan Moral dan

Nilai-nilai Keagamaan bagi Anak Usia

Dini., (Jakarta: Grasindo, 2017)

Helmawati, Pendidik sebagai Model, (Bandung: PT Rosdakarya, 2015)

---_-----,Mengenal dan memahami PAUD,

(Bandung:PT Rosdakarya, 2015)

Iskandarwassid dan Dadang Sunendar. Strategi Pembelajaran Bahasa.(

Bandung: Rosdakarya. 2013)

Moeslichatoen, Metode Pengajaran di Taman Kanak-kanak. (Jakarta: Rineka Cipta)

Mursyid, Belajar dan Pembelajaran PAUD, (Bandung:PT Rosdakarya)

Safrudin Aziz, Strategi Pembelajaran Aktif Anak Usia Dini; Pandua Bagi Guru, Orang Tua, Konselor, dan Praktisi Anak Usia Dini, (Yogyakarta: Kalimedia, 2017)

Suyadi dan Maulidya Ulfah, Konsep Dasar PAUD,(Bandung: Rosdakarya, 2015)

Syamsu Yusuf, Psikologi Perkembangan Anak dan Remaja. (Bandung: Rosdakarya, 2012)

Tadkiroatun Musfiro, Bercerita Untuk Anak Usia Dini. (Jakarta: Departemen Pendidikan Nasional Direktorat Jenderal Pendidikan Tinggi Direktorat Pembinaan Pendidikan Tenaga Kependidikan dan Ketenagaan Perguruan Tinggi,2005)

UU No.20 tahun 2003 tentang Sistem Pendidikan Nasional

Yuliani Nuraini Sujono, Konsep Dasar Pendidikan Anak Usia Dini, (Jakarta: PT Indeks, 2009)

Zusy Aryanti, Psikologi Perkembangan. (STAIN JuraiSiwo Metro, 2015) 